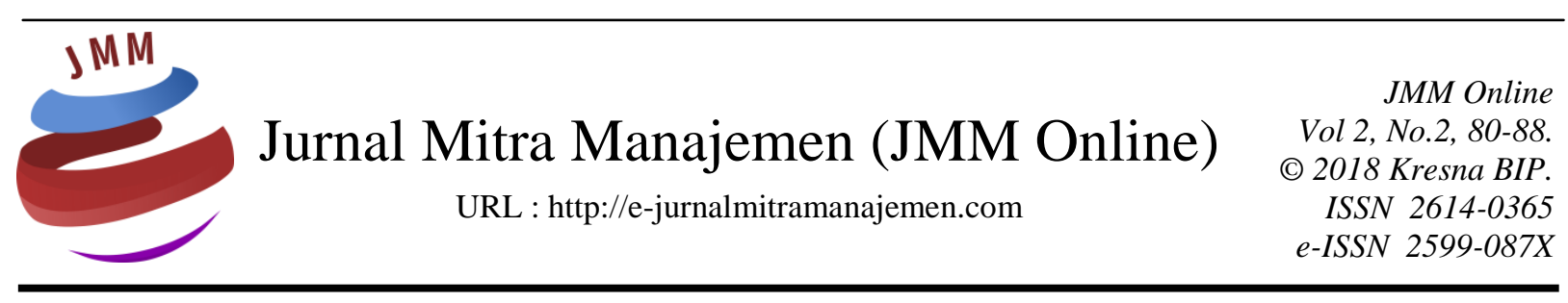

\title{
ANALISIS PENDAPATAN USAHA PAPRIKA DI DESA PANCASARI KECAMATAN SUKASADA KABUPATEN BULELENG
}

\author{
Kadek Duwika \\ Politeknik Ganesha Guru
}

\section{INFORMASI ARTIKEL}

Dikirim :02 April 2018

Revisi pertama : 05 April 2018

Diterima : 06 April 2018

Tersedia online : 13 April 2018

Kata Kunci : Analisis Pendapatan, Usaha Paprika

Email : kadekduwika@gmail.com

\section{ABSTRAK}

Penelitian ini bertujuan untuk mengetahui pedapatan usaha pertanian khususnya yang memiliki mata pencaharian sebagai petani, sehingga sektor pertanian memegang peranan penting. Sektor pertanian terdiri dari beberapa sub sektor yang meliputi tanaman bahan makanan, peternakan, perkebunan, perikanan, kehutanan, dan hortikultura. Hortikultura merupakan salah satu potensi dalam pembangunan pertanian. Produk hortikultura yang meliputi tanaman sayuran, tanaman buah-buahan, tanaman obat dan tanaman hias mempunyai kontribusi yang besar terhadap manusia dan lingkungan. Paprika merupakan salah satu komoditas sayuran komersial yang dapat dibudidayakan secara hidroponik. Saat ini penanaman paprika terus dikembangkan karena adanya kebutuhan pasar yang terus meningkat, sehingga prospek yang cerah untuk dibudidayakan ( Prihmantoro, 2003). Hasil penjualan paprika dalam satu musim tanam adalah sebesar Rp 158.400.000,00 per 400 m2. Biaya usaha tani Paprika adalah seluruh komponen biaya yang dikeluarkan oleh petani dalam menjalankan usaha tani paprika. Biaya total yang dikeluarkan terdiri atas biaya tunai dan biaya yang diperhitungkan biaya tidak tunai sebesar Rp. 16. 587.000. Total keuntungan yang didapat petani dari usaha tani paprika adalah Rp. 93.013.000,/tahun/petani. 


\section{PENDAHULUAN \\ Latar Belakang}

Indonesia adalah negara agraris yang sebagian besar penduduknya bermata pencaharian sebagai petani, sehingga sektor pertanian memegang peranan penting. Sektor pertanian terdiri dari beberapa sub sektor yang meliputi tanaman bahan makanan, peternakan, perkebunan, perikanan, kehutanan dan hortikultura. Hortikultura merupakan salah satu potensi dalam pembangunan pertanian. Produk hortikultura yang meliputi tanaman sayuran, tanaman buah-buahan, tanaman obat dan tanaman hias mempunyai kontribusi yang besar terhadap manusia dan lingkungan. Dari ketiga jenis produk hortikultura, sayuran memiliki manfaat yang besar bagi kehidupan manusia diantaranya sebagai sumber pangan dan gizi, pendapatan keluarga dan pendapatan Negara (Ashari, 1995:171).

Produk sayuran memiliki peluang yang baik di pasaran. Paprika merupakan salah komoditas sayuran komersial yang dapat dibudidayakan secara hidroponik. Saat ini penanaman paprika terus dikembangkan karena adanya kebutuhan pasar yang terus meningkat, sehingga prospek yang cerah untuk dibudidayakan ( Prihmantoro, 2003). Paprika merupakan tanaman hortikultura yang dimanfaatkan untuk keperluan pangan. Selain itu paprika juga digunakan dalam industri farmasi untuk membuat ramuan obatobatan, kosmetik dan pewarna bahan makanan. Paprika merupakan tanaman komoditas sayuran yang penting, yang tidak dapat dipisahkan dari kehidupan masyarakat seharihari. Pemanfaatannya sebagai bahan baku industri menjadikan paprika sebagai komoditas yang bernilai ekonomis tinggi dan mempunyai peluang bisnis yang cerah. Selain digunakan untuk konsumsi rumah tangga dan masakan luar negeri, berbagai kelompok industri pengolahan makanan yang menggunakan paprika sebagai bahan baku utama/bahan campuran antara lain: industri mie, bihun, kecap, krupuk dan sebagainya. Menurut data Badan Pusat Statistik tahun 2014, komoditas paprika di Indonesia yang berkembang masih di 9 Provinsi.

Tabel 1. Luas Panen, Produksi dan Rata-Rata Hasil Paprika Indonesia

Tahun 2014

\begin{tabular}{|c|c|c|c|c|}
\hline No. & Propinsi & $\begin{array}{l}\text { Luas } \\
\text { (ha) }\end{array}$ & Produksi & Produktivitas \\
\hline 1 & Sumatera Selatan & 13 & 3 & 0,25 \\
\hline 2 & Jawa Barat & 86 & 4.490 & 52,51 \\
\hline 3 & Jawa Tengah & 5 & 13 & 2,56 \\
\hline 4 & Jawa Timur & 173 & 361 & 11,94 \\
\hline 5 & Bali & 9 & 11 & 40,14 \\
\hline 6 & Nusa Tenggara Barat & 3 & 73 & 3,53 \\
\hline 7 & Sulawesi Selatan & 5 & 11 & 14,64 \\
\hline 8 & Sulawesi Barat & 8 & 4 & 1,4 \\
\hline 9 & Maluku & 14 & 7.031 & 0,27 \\
\hline \multicolumn{2}{|r|}{ Total } & 316 & 7.031 & 22,25 \\
\hline
\end{tabular}

Sumber : Statistik Produksi Hortikultura, 2014 
Dari data tersebut dapat disimpulkan bahwa pulau Jawa merupakan sentra produksi paprika Indonesia, dengan total produksi tahun 2014 mencapai 4.490 ton dengan luas panen 86 ha. Sehingga dapat disimpulkan Provinsi Jawa Barat merupakan sentra utama penghasil paprika terbesar di Indonesia, kemudian diikuti oleh Jawa Timur, Bali, Sulawesi Selatan, Jawa Tengah, Nusa Tenggara Barat, Sulawesi Barat, Maluku dan kemudian Sumatera Selatan. Provinsi Bali juga merupakan salah satu penghasil paprika di Indonesia. Salah satu sentra produksi paprika di Bali adalah Desa Pancasari, Kecamatan Sukasada, Kabupaten Buleleng. Daerah ini merupakan salah satu desa dari 14 desa di wilayah kecamatan Sukasada, Kabupaten Buleleng Provinsi Bali, sesuai dengan keadaan alam desa Pancasari merupakan daerah pegunungan, dengan ketinggian antara 1000-1100 meter dari permukaan laut dengan luas wilayah $12,80 \mathrm{~km}^{2}$. Desa Pancasari berhawa sejuk dengan temperatur $23-25^{\circ} \mathrm{C}$.

Dalam melakukan usaha tani paprika analisa biaya dan pendapatan merupakan awal dalam menentukan sikap untuk melakukan budidaya paprika. Analisis perhitungan dilakukan untuk memberikan gambaran mengenai produksi dan harga jual yang pada akhirya akan berpengaruh terhadap pendapatan petani dalam berusahatani paprika.Usahatani paprika skalanya relatif kecil dan adanya ketergantungan terhadap harga jual yang selalu berfluktuasi setiap waktu akan mempengaruhi hasil usahatani serta pendapatan petani. Melihat fenomena tersebut mendorong penulis untuk melaksanakan penelitian mengenai Analisis Pendapatan Usahatani Paprika di Desa Pancasari, Kecamatan Sukasada, Kabupaten Buleleng.

\section{Rumusan Masalah}

Berdasarkan latar belakang masalah yang telah diuraikan di peneliti diatas, maka permasalahan yang akan dibahas dalam penelitian ini adalah Berapa biaya dan pendapatan usaha paprika serta berapa R/C ratio, B/C ratio, Break Event Point (BEP) usaha paprika di Desa Pancasari Kecamatan Sukasada Kabupaten Buleleng.

\section{Tujuan Penelitian}

Dengan demikian tujuan penelitian ini adalah ingin mengetahui berapa biaya dan pendapatan usaha paprika dan berapa R/C ratio, B/C ratio, Break Event Point (BEP) usaha paprika yang berada di Desa Pancasari Kecamatan Sukasada Kabupaten Buleleng.

\section{KAJIAN PUSTAKA \\ Definisi Pafrika}

Paprika (Capsicum annuum L) merupakan varietas cabai yang memiliki bentuk yang berbeda dari cabai lain. Bentuknya besar seperti buah kesemek yang memiliki rasa tidak pedas dan sedikit manis. Paprika terdiri dari beberapa warna yaitu paprika merah, paprika kuning, dan paprika hijau. (W.D Herawati, 2012).

Paprika memiliki nama ilmiah Capsicum annuum L. Buah ini termasuk Family Solanaceae. Untuk lebih jelasnya, klasifikasi paprika sebagai berikut :

Divisio : Spermatophyta

Subdivision : Angiospermae

Kelas : Dicotyledoneae 


$\begin{array}{ll}\text { Ordo } & : \text { Solanoles } \\ \text { Family } & : \text { Solanaceae } \\ \text { Genus } & : \text { Capsicum } \\ \text { Spesies } & : \text { Capsicum annuum } \\ \text { Varietas } & : \text { Grossum }\end{array}$

Paprika memiliki salah satu kandungan antioksidan yaitu capsiate. Menurut sebuah studi yang dilakukan oleh Catholic Research Institute of Medical Science, capsiate sangat baik untuk menangkal radiasi sinar UVB yang dapat menyebabkan kulit menjadi gosong dan dapat mencegah peradangan kulit. Paprika juga memiliki kandungan vitamin A sehingga sangat baik untuk kesehatan mata karena dapat menghalangi paparan sinar ultraviolet yang akan mengenai lensa mata yang dapat mengakibatkan katarak. Paprika juga baik untuk mencegah penyakit jantung koroner, kanker, stroke dan diabetes militus. Kandungan vitamin B6 dan asam folat yang ada di dalam paprika dapat berkhasiat untuk mencegah atherosklerosis (Lanny Lingga, 2012).

\section{Pengertian Usaha}

Jika diartikan secara general, usaha merupakan setiap aktivitas yang dilakukan manusia untuk mendapatkan apa yang diinginkan. Jika diartikan secara khusus, istilah usaha dapat diartikan ke dalam banyak makna dan sangat bergantung dengan dimana istilah usaha ini digunakan. Di bidang bisnis misalnya, usaha biasanya identik dengan aktivitas bisnis, sedangkan di dunia fisika, usaha merupakan faktor dari perpindahan dengan gaya. Menurut Kamajaya, pengertian usaha (dalam ilmu fisika) adalah perpindahan energi melalui gaya yang membuat benda menjadi berpindah. Menurut Wasis dan Sugeng Yuli Irianto, usaha pada umunya merupakan upaya manusia yang ditujukan untuk bisa mencapai suatu tujuan tertentu. Sedangkan usaha dalam ilmu sains merupakan gaya yang diberikan sebuah benda yang dapat menciptakan perpindahan posisi benda tersebut.

\section{METODE PENELITIAN}

Jenis penelitian yang digunakan adalah penelitian lapangan (Field Research). Menurut Kenneth D. Bailey (1994:254) istilah studi lapangan merupakan istilah yang sering digunakan bersamaan dengan istilah studi etnografi (ethnographic study atau ethnography). Lawrence Neuman (2003:363) juga menjelaskan bahwa penelitian lapangan juga sering disebut etnografi atau penelitian participant observation. Akan tetapi, menurut Neuman etnografi hanyalah merupakan perluasan dari penelitian lapangan. Etnografi mendefinisikan kembali bagaimana penelitian lapangan harus dilakukan. Menurut Roice Singleton (1988:308), penelitian lapangan berasal dari dua tradisi yang terkait yakni antropologi dan sosiologi, dimana etnografi merupakan studi antropologi dan etnometodologi merupakan studi sosiologi. Etnografi memberikan jawaban atas pertanyaan apakah budaya suatu kelompok individu, sedangkan etnomethodologi memberikan jawaban atas bagaimanakah orang memahami kegiatan mereka sehari-hari sehingga mereka dapat berprilaku dengan cara yang diterima secara sosial.

Jenis data yang digunakan dalam penelitian ini adalah data primer dan sekunder. Data primer diperoleh dari peninjauan langsung ke lapangan dan wawancara 
langsung kepada petani paprika di Desa Pancasari, Kecamatan Sukasada, Kabupaten Buleleng. Data sekunder diperoleh dari berbagai literatur instansi yang terkait dengan permasalahan penelitian seperti Badan Pusat Statistika, Profil Desa Pancasari dan Media Online. Variabel penelitian adalah satu atribut atau sifat atau nilai dari orang, obyek atau kegiatan yang mempunyai variasi yang diterapkan oleh peneliti untuk dipelajari kemudian ditarik kesimpulan (Sugiyono, 2009:61). Variabel yang digunakan dalam penelitian ini adalah variabel bebas dan variabel terikat. Variabel Independent (bebas) adalah variabel yang dapat mempengaruhi atau menjadi penyebab perubahan atau timbulnya variabel dependen (terikat). Sedangkan variabel dependen (terikat) adalah hasil yang ditimbulkan oleh variabel bebas. Dalam penelitian ini menggunakan variabel bebas yaitu paprika dan pendapatan sebagai variabel terikatnya.

Metode pengumpulan data merupakan metode-metode yang dipergunakan dalam penelitian untuk memperoleh data. Data yang dikumpulkan dalam penelitian ini terdiri dari data primer dan data sekunder. Data primer merupakan data yang diperoleh langsung dari lapangan oleh orang yang melakukan penelitian atau yang bersangkutan yang memerlukannya, sedangkan data sekunder adalah data yang diperoleh atau dikumpulkan oleh orang yang melakukan penelitian dari sumber-sumber yang telah ada, biasanya diperoleh dari instansi terkait (Hasan, Iqbal, 2008; 19). Metode Pengamatan (Observasi) Observasi adalah cara dan teknik pengumpulan data dengan melakukan pengamatan secara sistematis terhadap gejala atau fenomena yang ada pada objek penelitian. Observasi dapat dibagi menjadi dua, yaitu observasi langsung dan observasi tidak langsung (Pabundu Tika, 2005:44). Dalam melakukan survei langsung di lapangan untuk mendapatkan informasi mengenai Analisis Pendapatan Usahatani Paprika di Desa Pancasari, Kecamatan Sukasada, Kabupaten Buleleng, pada saat kegiatan kerja sosial Universitas Mahendradatta yang dilaksanakan pada tanggal 2 sampai 4 Februari 2018. Metode Wawancara merupakan bentuk komunikasi verbal semacam percakapan yang bertujuan memperoleh informasi. Wawancara merupakan metode pengumpulan data dengan cara tanya jawab yang dikerjakan dengan sistematis dan berdasarkan pada tujuan penelitian. Data sekunder diperoleh melalui dokumen, dapat berupa informasi tentang kondisi geografis seperti letak, luas, batas, iklim, dan data demografis. Data sekunder diperoleh dari Dinas terkait dan berdasarkan pengamatan di lapangan.

\section{HASIL DAN PEMBAHASAN Hasil Penelitian}

Hasil penelitian ini mengemukakan bahawa dari 14 Desa di wilayah Kecamatan Sukasada, Kabupaten buleleng Provinsi Bali, sesuai dengan keadaan alam desa Pancasari yang merupakan daerah pegunungan, dengan ketinggian antara 1000 1100 meter dari permukaan laut dengan luas wilayah $12,80 \mathrm{~km}^{2}$. Dilihat dari jarak tempuhnya Desa Pancasari berada cukup jauh dari pusat pemerintahan Kabupaten maupun Provinsi. Jarak ke kecamatan sejauh 20 km, ke kabupaten sejauh 24 km, ke Ibu Kota Provinsi sejauh $45 \mathrm{~km}$. Desa Pancasari yang berhawa sejuk dengan curah hujan rata-rata $2.500 \mathrm{~mm} /$ tahun dengan temperatur antara 23-25 derajat Celcius, namun jika dilihat dari sudut iklim desa pancasari memiliki iklim tropis yang terdiri 
dari Musim hujan antara bulan Oktober sampai dengan Maret dan musim kemarau antara bulan April sampai dengan September.

Desa Pancasari dengan luas wilayah $12,80 \mathrm{~km}^{2}$ terdiri dari keseluruhan wilayah yang ada dipergunakan untuk pertanian dan perkebunan yang mHa. Analisis pendapatan usaha tani paprika meliputi analisis penerimaan, analisis biaya, analisis pendapatan dan analisis R/C. Perhitungan usaha tani paprika dalam penelitian ini dilakukan untuk satu periode tanam, mulai dari persiapan tanam hingga panen. Untuk memudahkan perhitungan dan analisis, luasan lahan green house dalam penelitian ini telah dikonversi menjadi $400 \mathrm{~m}^{2}$. Alasan lainnya dalam pengambilan luasan tersebut yaitu karena luasan lahan green house yang dimiliki Pak Sama selaku responden ratarata sebesar $400 \mathrm{~m}^{2}$. Analisis terhadap penerimaan usahatani paprika di Desa Pancasari merupakan analisis atas penerimaan tunai.

Penerimaan tunai merupakan penerimaan yang langsung diperoleh dalam bentuk uang tunai dari hasil penjualan paprika. Penerimaan tidak tunai tidak dimasukkan ke dalam analisis dengan pertimbangan bahwa seluruh hasil panen paprika yang dihasilkan oleh responden langsung dijual dan tidak ada yang disimpan untuk konsumsi rumah tangga ataupun digunakan untuk bibit. Penerimaan usaha tani paprika dihitung dari hasil perkalian antara jumlah produksi paprika yang dihasilkan selama satu periode tanam dengan harga jual rata-rata yang diterima petani. Jumlah rata-rata produksi paprika di lokasi penelitian pada musim tanam terakhir adalah 4.400 $\mathrm{kg}$ per $400 \mathrm{~m}^{2}$. Harga jual paprika merah, kuning dan hijau digunakan harga rata-rata yaitu $\mathrm{Rp} 36.000 / \mathrm{kg}$. Dengan demikian penerimaan tunai sekaligus penerimaan total yang diperoleh petani responden dari hasil penjualan paprika dalam satu musim tanam adalah sebesar Rp 158.400.000,00 per $400 \mathrm{~m}^{2}$. Biaya usaha tani Paprika adalah seluruh komponen biaya yang dikeluarkan oleh petani Pak Sama dalam menjalankan usaha tani paprika. Biaya total yang dikeluarkan terdiri atas biaya tunai dan biaya yang diperhitungkan biaya tidak tunai sebesar Rp. 16.587.000. Total keuntungan yang didapat petani dari usaha tani paprika adalah Rp. 93.013.000,-/tahun/petani.

Pendapatan usaha tani paprika ini telah cukup memadai karena pendapatan yang diperoleh telah cukup untuk membayar seluruh biaya pembelian sarana produksi termasuk seluruh komponen biaya administrasi yang melekat pada pembelian tersebut. Usaha tani paprika menurut penulis dan didukung data serta analisis memang sudah pantas dikatakan berhasil karena penerimaan yang diperoleh sudah mencukupi untuk membayar seluruh biaya yang dikeluarkan setiap petani selama masa tanam baik tunai maupun yang diperhitungkan dan masih menghasilkan selisih yang signifikan antara pengeluaran dan pemasukan berupa laba/keuntungan.

Tabel 2. Rata-Rata Keuntungan Usahatani Paprika di Desa Pancasari, Kecamatan Sukasada Kabupaten Buleleng

\begin{tabular}{|l|l|l|}
\hline No & Uraian & Nilai/Tahun/Petani (Rp) \\
\hline 1 & Penerimaan & 158.400 .000 \\
\hline 2 & Biaya Tunai & 16.587 .000 \\
\hline 3 & Biaya Diperhitungkan & 48.800 .000 \\
\hline
\end{tabular}




\section{Lanjutan Tabel 2. Rata-Rata Keuntungan Usahatani Paprika di Desa Pancasari, Kecamatan Sukasada Kabupaten Buleleng

\begin{tabular}{|l|l|l|}
\cline { 3 - 3 } 4 & Biaya Total & 65.387 .000 \\
\hline 5 & $\begin{array}{l}\text { Keuntungan atas Biaya } \\
\text { Tunai }\end{array}$ & 93.013 .000 \\
\hline 6 & $\begin{array}{l}\text { Keuntungan atas Biaya } \\
\text { Total }\end{array}$ & 93.013 .000 \\
\hline
\end{tabular}

Sumber: Data Primer, diolah (2018)

Keuntungan relatif dari usahatani paprika ini dapat dihitung dengan menggunakan analisis $\mathrm{R} / \mathrm{C}$ ratio. Nilai $\mathrm{R} / \mathrm{C}$ ratio adalah perbandingan antara penerimaan dengan biaya produksi. Analisis rasio dalam penelitian ini dibedakan menjadi dua bagian yaitu $\mathrm{R} / \mathrm{C}$ ratio atas biaya tunai dan $\mathrm{R} / \mathrm{C}$ ratio atas biaya total. Analisis R/C ratio usahatani paprika. nilai R/C ratio atas biaya tunai sebesar 9,55. Hal ini berarti setiap Rp 1.000,- biaya yang dikeluarkan petani paprika dalam menjalankan usahatani paprika akan memberikan penerimaan sebesar 9.550. Sedangkan nilai R/C ratio atas biaya total diperoleh sebesar 2,42 yang mengindikasikan bahwa setiap Rp. $1.000,-$ atas biaya keseluruhan yang dikeluarkan akan memberikan penerimaan sebesar Rp. 2.420,- kepada petani paprika di Desa Pancasari, Kecamatan Sukasada, Kabupaten Buleleng. Perbandingan antara pendapatan yang diperoleh dengan biaya yang dikeluarkan dalam menjalankan usahatani paprika di Desa Pancasari, Kecamatan Sukasada, Kabupaten Buleleng ini merupakan analisis yang digunakan untuk melihat tingkat nilai pendapatan yang diperoleh dari setiap rupiah yang dikeluarkan. Nilai B/C ratio yang digunakan pada analisis ini meliputi nilai $\mathrm{B} / \mathrm{C}$ ratio atas biaya tunai dan nilai $\mathrm{B} / \mathrm{C}$ ratio atas biaya total.

Berdasarkan keuntungan dan biaya yang dikeluarkan, nilai B/C ratio atas biaya tunai adalah 8,55, artinya setiap Rp. 1.000,- untuk biaya tunai akan menghasilkan keuntungan sebanyak Rp. 8.550,- B/C ratio atas biaya total yang diperoleh adalah sebesar 1,42. Hal ini menunjukkan bahwa dengan $\mathrm{B} / \mathrm{C}$ ratio sebesar 1,42 berarti untuk setiap penambahan biaya total sebesar Rp. 1.000,- maka usahatani paprika di desa Pancasari, Kecamatan Sukasada, Kabupaten Buleleng akan memperoleh keuntungan atau pendapatan sebesar Rp. 1.420,-. Untuk perhitungan B/C ratio, sesuai dengan teori Rahardi dan Hartono bahwa suatu usaha dikatakan layak dan memberikan manfaat apabila nilai $\mathrm{B} / \mathrm{C}$ lebih besar dari nol $(\mathrm{B} / \mathrm{C}>0)$. Semakin besar nilai $\mathrm{B} / \mathrm{C}$ maka semakin besar nilai manfaat yang akan diperoleh dari usaha tersebut. Dari hasil perhitungan nilai B/C ratio usahatani paprika di desa Pancasari, Kecamatan Sukasada, Kabupaten Buleleng tersebut maka dengan kata lain $\mathrm{B} / \mathrm{C}>0$ hal ini berarti bahwa usahatani paprika di desa Pancasari, Kecamatan Sukasada, Kabupaten Buleleng dapat memberikan manfaat atau menguntungkan dan layak untuk dilanjutkan.

Hasil diatas menunjukkan bahwa nilai BEP rata-rata yang diperoleh petani pada usahatani paprika di desa Pancasari, Kecamatan Sukasada, Kabupaten Buleleng adalah BEP produksi paprika $1.816 \mathrm{~kg}$ serta BEP harga untuk paprika Rp.14.861,-Semua hasil itu menunjukkan bahwa usahatani paprika tersebut tidak untung dan tidak rugi pada level tersebut. Usaha tersebut baru akan mulai mendapat keuntungan jika output lebih besar dari nilai BEP produksi dan harga hasil perhitungan diatas. 
Usahatani paprika mendapat keuntungan dari selisih produksi yang dihasilkan dari total produksi rata-rata $2584 \mathrm{~kg} /$ petani, sedangkan selisih keuntungan harga yang didapatkan petani masing-masing adalah Rp. 21.139,-/ kg.

\section{KESIMPULAN DAN SARAN \\ Kesimpulan}

Berdasarkan analisis hasil penelitian dan pembahasan mengenai pendapatan usahatani paprika di Desa Pancasari dapat ditarik beberapa kesimpulan: Penerimaan total yang diperoleh petani dalam satu musim dengan luas lahan $400 \mathrm{~m} 2$ adalah sebesar Rp. 158.400.000,-. Rata-rata biaya total usaha tani paprika adalah Rp. 65.387.000. Nilai $\mathrm{R} / \mathrm{C}$ rasio atas biaya total sebesar 2,42 dan nilai $\mathrm{B} / \mathrm{C}$ ratio atas biaya total sebesar 1,42. Dengan nilai $\mathrm{R} / \mathrm{C}$ ratio atas biaya total sebesar 2,42 dan $\mathrm{B} / \mathrm{C}$ ratio atas biaya total sebesar 1,42 menunjukan bahwa kondisi usahatani paprika ini layak untuk dijalankan dan memiliki prospek yang bagus untuk dikembangkan. BEP ratarata yang diperoleh petani pada usahatani paprika di desa Pancasari, Kecamatan Sukasada, Kabupaten Buleleng adalah BEP produksi paprika $1.816 \mathrm{~kg}$ serta BEP harga untuk paprika Rp.14.861,- . Semua hasil itu menunjukkan bahwa usahatani paprika tersebut tidak untung dan tidak rugi pada level tersebut. Usaha tersebut baru akan mulai mendapat keuntungan jika output lebih besar dari nilai BEP produksi dan harga hasil perhitungan diatas. Usahatani paprika mendapat keuntungan dari selisih produksi yang dihasilkan dari total produksi rata-rata $2584 \mathrm{~kg} /$ petani, sedangkan selisih keuntungan harga yang didapatkan petani masing-masing adalah Rp. 21.139, $/ \mathrm{kg}$. Berdasarkan hasil perhitungan pendapatan, $\mathrm{R} / \mathrm{C}$ rasio, $\mathrm{B} / \mathrm{C}$ rasio dan Break Event Point (BEP). Dengan $\mathrm{R} / \mathrm{C}>1, \mathrm{~B} / \mathrm{C}>0$ serta $\mathrm{BEP}$ produksi di bawah produksi real dan BEP harga di bawah harga real maka dapat diketahui bahwa usahatani paprika ini layak untuk dijalankan dan memiliki prospek usaha yang bagus untuk dikembangkan.

\section{Saran}

Berdasarkan kesimpulan diatas, ada beberapa saran yang penulis sampaikan : Data hasil penelitian menunjukkan bahwa usahatani paprika di desa Pancasari, Kecamatan Sukasada, Kabupaten Buleleng ini sangat menguntungkan dan efektif, hal tersebut juga menunjukkan bahwa usahatani paprika ini mempunyai prospek yang bagus untuk dikembangkan dengan cara penambahan luas area tanam. Dengan bertambahnya luas areal serta pengelolaan yang bagus akan meningkatkan produksi dan diikuti dengan bertambahnya pendapatan petani.

\section{DAFTAR PUSTAKA}

Adi, Wijaya (penyunting) 2005. Otonomi Daerah dan Optimalisasi, Pemanfaatan Sumber Daya Ekonomi.Jakarta.P2E-LIPI

Analisis Korelasi, Regresi, dan Jalur dalam Penelitian (Dilengkapi Aplikasi ProgramSPSS) Sambas Ali Muhidin 2015

Arya, 2011.Budidaya Rumput Metode Nusa Penida

Dinas Kelautan dan Perikanan Kabupaten Provinsi Bali. 2010. Budidaya Rumput Laut Provinsi Bali.

Hernanto. 2010. Ilmu Usahatani. Penebar Swadaya. Jakarta. 
Ken Suratiyah :Ilmu Usahatani (Edisi Revisi) Tahun 2015

Rawirokusumo, S. 2010. Ilmu Usahatani. Yogyakarta : Universitas Gajah Mada

Rusli Syarif. 2011. Ilmu Usaha Tani dan Penelitian Untuk Pengembangan Petani Kecil.Jakarta : Universitas Indonesia.

RH LIEMBONO \& A. RUDY MULYANA : Analisis Fundamental 2 Tahun 2017

Soekartawi, 2006 Analisis Usahatani.Jakarta :UI Press.

Suratiyah, K. 2012. Ilmu Usahatani.Jakarta : Penebar Swadaya

Suratiyah. 2011. Ilmu Usahatani. Penebar Swadaya. Jakarta.

Soekartawi. Edisi 2011. Ilmu Usahatani.Jakarta : Penerbit Universitas Indonesia

Shinta, Agustina. 2011. Ilmu Usahatani . UB Press: Malang

http://digilib.unimus.ac.id/download.php?id=17279 